Table 2 Group data during and after the period of selective decontamination. Values are expressed as mean (range) for the group of 12 patients

\begin{tabular}{lll}
\hline & $\begin{array}{l}\text { Selective } \\
\text { decontamination } \\
\text { period (90 days) }\end{array}$ & $\begin{array}{l}90 \text { Days after } \\
\text { decontamination } \\
\text { period }\end{array}$ \\
\hline $\begin{array}{l}\text { No of episodes upper } \\
\text { respiratory tract } \\
\text { infections }\end{array}$ & $0.8(0-3)$ & $1.1(0-3)$ \\
$\begin{array}{l}\text { No of episodes lower } \\
\text { respiratory tract } \\
\text { infections }\end{array}$ & $1.9(1-4)$ & $1.8(1-3)$ \\
$\begin{array}{l}\text { Weight gain (kg) } \\
\text { No of courses } \\
\text { additional antibiotics }\end{array}$ & $2.9(-0.6-5 \cdot 75)$ & $1.4(0.15-3.3)$ \\
\hline
\end{tabular}

There was no significant difference for any of the above variables between the selective decontamination period and the subsequent 90 days.

to complete the study: one did not fulfill the entry criteria and two patients did not like applying the oral gel. Clinical details of the 12 patients who completed the study are shown in table 1.

Ten patients $(83 \%)$ continued to yield $P$ aeruginosa from the throat and sputum during the treatment period and from the oropharynx during the three months after completion of the study $(p=0 \cdot 3) . P$ aeruginosa was intermittently cultured from rectal swabs taken from three patients during the study period.

Table 2 shows clinical data for the selective decontamination period and the subsequent 90 days. There was no detectable benefit to the patient during the selective decontamination period in terms of weight gain or reduced frequency of respiratory exacerbations.

\section{Discussion}

Together with Staphylococcus aureus and Haemophilus influenzae, $P$ aeruginosa is the commonest isolate from the oropharynx of patients with cystic fibrosis. Sporadic isolates of $P$ aeruginosa are not unusual in patients with cystic fibrosis, but once oropharyngeal carriage has occurred, eradication is rare. The application of an oral selective decontamination gel was of no benefit to 10 out of 12 patients in preventing carriage of $\boldsymbol{P}$ aeruginosa within the oropharynx. The organism ultimately colonises most patients and has at least two strategies to facilitate survival. Once established in the respiratory tract, mucoid variants are commonly found. The 'slime' probably protects colonies from host defences, and intramural proteins have been identified in $P$ aeruginosa, which may protect against antibiotic attack. Pseudomonas is not an oropharyngeal commensal, nor is it cultured from stool unless a large inoculum $\left(10^{6}\right)$ is ingested orally. Even then, in normal individuals colonisation of the bowel does not occur. ${ }^{4}$ Three patients were identified as having pseudomonal colonisation of the bowel because of repeated isolates from rectal swabs during attempted oral selective decontamination.

The failure of a selective decontamination approach in cystic fibrosis may be due to a number of factors. Lindemann $e t$ al found that the orophyarynx is a reservoir for the organism which may colonise by virtue of its preferred attachment to altered epithelial surfaces in the oropharynx of cystic fibrosis patients. ${ }^{5}$ In contrast to the success achieved in ventilated patients where an antibiotic containing paste has been effective, ${ }^{2}$ it was necessary to use an antibiotic containing gel because of the unpalatability of paste. The mucosal contact time of the gel compared with paste may have reduced antibiotic effectiveness. The reasons why patients with cystic fibrosis are colonised by $P$ aeruginosa are still unclear, and the difficulties encountered in trying to prevent carriage of the organism remain.

AMD is in receipt of a cystic fibrosis research fellowship.

1 van Saene HKF, Stoutenbeek CP. Leading article. Selective decontamination. 7 Antimicrob Chemother 1987;20:462-5.

Stoutenbeek CP, van Saene HKF, Miranda DR, Zandstra DF, Langrehr D. Nosocomial Gram-negative pneumonia in critically ill patients. Intensive Care Med 1986;12:419-23. in critically ill patients. Intensive Care Med 1986;12:419-23. odson ME, Penketh ARL, Batten JC. Aerosol carbenicillin and gentamicin treatment of Pseudomonas aeruginosa infection

4 Buck AC, Cooke EM. The fate of ingested Pseudomonas aeruginosa in normal persons. $\mathcal{J}$ Med Microbiol 1969;2: aerugin $521-5$

5 Lindemann RA, Newman MG, Kaufman AK, Le TV. Oral colonization and susceptibility testing of Pseudomonas aeruginosa oral isolates from cystic fibrosis patients. $\mathcal{F}$ Dent Res 1985;64:54-7.

\title{
Nocturnal faecal soiling and anal masturbation
}

\author{
A F Clark, P J Tayler, S R Bhate
}

Young People's Unit, Newcastle General Hospital,

Westgate Road,

Newcastle upon Tyne

NE4 6BE

A F Clark

P J Tayler

S R Bhate

Correspondence to:

Dr Clark.

Accepted 1 July 1990

(Anch Dis Child 1990;65:1367-8).

\section{Abstract}

Two cases of late onset faecal soiling as a result of anal masturbation in children who were neither mentally handicapped nor psychotic were studied. The role of soiling in aiding the young person and his family to avoid separating and maturing is highlighted. We suggest that the association of anal masturbation and resistant nocturnal soiling may be unrecognised.

Faecal soiling is defined as disordered bowel function and control occurring in children over a certain age in the absence of any physical abnormality or disease. ${ }^{1}$ The prognosis is good, with remission occurring before adulthood. This has made it difficult to assess the effectiveness of intervention. ${ }^{2}$ A steady decline in symptoms was recorded from the age of 6 years in boys and 8 years in girls in the follow up of 186 children attending child psychiatric clinics. ${ }^{3}$ All were clean by the age of 16 years, apart from two relapses, one at 17 and one at 19 years. It has been suggested that encopresis in adulthood is a feature of either psychotic disorder or severe mental handicap, and there have been reports of 
two instances of persistence into adulthood in which neurosis was the most prominent feature. ${ }^{4}$

We report two further cases of late onset faecal soiling persisting into adolescence without psychosis or mental handicap, but in which neurotic features were implicated. Anal masturbation was a feature of both cases, a factor not previously reported to our knowledge.

\section{Case reports}

CASE 1

At the age of 13 years a boy began to soil at night but not during the day. This always occurred at home. At the age of 17 he was referred for inpatient treatment after individual outpatient treatment had proved to be unsuccessful. While he was in a medical ward no physical abnormality was found and no soiling occurred.

The effect of his soiling within the home was that his mother prompted and controlled him in all areas of his life. Despite paid employment she took responsibility for his finances, she checked his clothes and bed each day, and absolved him from any household tasks.

He had no contact with his father who had left when he was 4 years old. His mother had a fiancé of 11 years' standing, but no plans to marry 'until the children leave home'.

His early developmental history was unremarkable. He had attended the local comprehensive school where he was of below average ability. On leaving school he obtained employment as a manual worker.

On direct questioning he readily admitted to inserting fingers into his anus since the age of 13. He stated that this had started as a means of overcoming feelings of constipation but admitted that it was now a habit that he enjoyed. He claimed to be heterosexually active without any homosexual feelings or desires. He had no recollection of being sexually abused. His mother acknowledged that she had been aware of his action but had not volunteered the information previously.

He was admitted for inpatient treatment consisting of a behavioural toileting programme and an emphasis on developing selfhelp and independent living skills. There were also meetings with his mother aimed at changing their unhelpfully close relationship. Under this plan he rapidly became clean and was able to maintain this for weekend visits at home. His mother, however, became increasingly anxious and upset at the distance she felt was being created between them. She found it difficult to look at her own circumstances and to face the reality of personal decisions she had been postponing.

At the time of discharge, therefore, the acute problems had resolved but the underlying family problems were unchanged.

\section{CASE 2}

A boy who had been soiling at night since he was 9 years old was referred to local and regional child psychiatric units when he was $13 \cdot 5$ years old. After referral his soiling ceased rapidly, only to relapse subsequently.

Admission to a child psychiatric inpatient unit was refused by the family. No physical abnormality or cause was found, and his stools were normally formed. He was reported to be a friendly boy with good peer and school relationships.

He came from an over close family in which the solution to his soiling was for him to sleep in the same room as another member of the family. On these nights he would not soil.

When referred to an adolescent unit at the age of 17 he was directly questioned about anal masturbation. He admitted inserting fingers into his anus and manually evacuating faeces into his underwear.

During psychotherapy he acknowledged that he derived pleasure from the insertion and evacuation. He emphasised his heterosexuality and denied any recollection of having been sexually abused. In the course of these individual sessions there was symptomatic improvement. When contacted by the unit 12 months later his soiling and masturbation were still continuing, but he did not keep further appointments.

\section{Discussion}

Published reports about anal masturbation in association with faecal soiling are few. Though there is some anecdotal evidence its prevalence is unknown. ${ }^{1}$ The rarity of pure nocturnal soiling is also highlighted with particular reference to the difficulty of treatment. ${ }^{5}$ Anal masturbation is a recognised form of sexual stimulation, which is in part a secondary and learnt phenomenon. ${ }^{6}$

In both these cases bowel control was normally established at an appropriate time and the behaviour was said to have begun in response to constipation. Only later did the patients become aware of the pleasurable component. The soiling that followed was clearly part of the difficulties that the families were having in coming to terms with adolescent separation and maturation. In a similar case soiling was used to maintain and justify a social phobia. ${ }^{4}$ Careful direct questioning and an appraisal of the family could indicate that this phenomenon is more common than expected in children with refractory night soiling in whom there is no adequate superficial explanation.

Awareness of this may permit paediatricians to ask tactful but direct questions and subsequently to refer such young people to child psychiatrists.

1 Hersov L Faecal soiling. In: Rutter M, Hersov L, eds. Child and adolescent psychiatry: modern approaches. Oxford: and adolescent psychiatry: moder

2 Halpern WI. The treatment of encopretic children. Fournal of the American Academy of Child Psychiatry 1977;16:478-99. Bellman M. Studies in encopresis. Acta Paediatr Scand 966;170(suppl): 1-137

4 Fraser AM, Taylor DC. Childhood encopresis extended into adult life. Brf Psychiatry 1986:149:370-1.

Levine MD. Encopresis: its potentiation, evaluation and alleviation. Pediatr Clin North Am 1982;29:315-30.

6 Bancroft J. Human sexuality and its problems. London Churchill Livingstone, 1989. 